\title{
PENGARUH AUKSIN DAN SITOKININ TERHADAP PERBANYAKAN MIKRO TANAMAN BINAHONG (Anredera cordifolia (Tenore) Steenis)
}

\author{
Effect of Auxin and Cytokinin on Micropropagation of Binahong (Anredera \\ cordifolia (Tenore) Steenis)
}

Suparjo, Juwartina Ida Royani, Syofi Rosmalawati, Teuku Tajuddin, Ahmad Riyadi Balai Bioteknologi, BPPT, Kawasan PUSPIPTEK Gedung 630, Setu, Tangerang Selatan E-mail: suparjo3630@bppt.go.id

\begin{abstract}
Binahong (Anredera cordifolia (Tenore) Steenis) is known as miraculous medicinal plant for its potential to cure for various kinds of diseases such as diabetes, stabilizing blood pressure and circulation, accelerating wound healing, and preventing stroke. In order to provide high quality seedlings of this medicinal plant continuously in large amount, the study on binahong micropropagation was performed. Plant growth regulators of auxins and cytokinins were applied in single or in combination so as to observe their effect on the growth of binahong explants. The results showed that 2,4-D induced callus formation in large diameter on all treatments. Nevertheless, this plant growth regulator had a negative effect on growth and development of shoot and leaves. In the combination treatments between IAA and BAP, it revealed that the higher the concentration of $B A P$ in the media, the lower the number of leaves initiated on shoot explants. Increasing the concentration of IAA upto $1.5 \mathrm{ppm}$ influenced the increasing of shoot tallness and the number of internodes. Our results can be useful for improving the binahong shoot propagation efficiency, as well as callus culture studies.
\end{abstract}

Keywords: Auxin, cytokinin, callus, micropropagation, medicinal plant

\section{ABSTRAK}

Binahong (Anredera cordifolia (Tenore) Steenis) dikenal sebagai tanaman obat ajaib karena dapat digunakan untuk pengobatan berbagai macam penyakit seperti diabetes, melancarkan peredaran dan tekanan darah, mempercepat penyembuhan luka, mencegah stroke. Dalam mendukung ketersediaan bibit tanaman obat herbal yang berkualitas secara berkelanjutan maka dilakukan kajian tentang perbanyakan bibit tanaman binahong. Zat pengatur tumbuh auksin dan sitokinin dalam bentuk tunggal maupun kombinasi diaplikasikan pada penelitian ini untuk melihat pengaruhnya terhadap berbagai eksplan binahong. Hasilnya menunjukkan bahwa 2,4-D merangsang pembentukan kalus dengan ukuran yang besar pada semua perlakuan. Namun demikian zat pengatur tumbuh ini memberikan pengaruh negatif terhadap pertumbuhan dan perkembangan tunas dan daun. Dari perlakuan kombinasi zat pengatur tumbuh IAA dan BAP, pertambahan konsentrasi BAP di dalam media menurunkan jumlah daun yang terbentuk pada eksplan pucuk binahong. Demikian pula dengan pertambahan konsentrasi IAA hingga 1,5 ppm sangat berpengaruh terhadap pertumbuhan meninggi tunas dan pertambahan jumlah ruas. Hasil dari studi ini dapat dimanfaatkan untuk studi lanjutan dalam meningkatkan efisiensi perbanyakan tunas serta kultur kalus binahong.

Kata kunci: Auksin, sitokinin, kalus, perbanyakan mikro, tanaman obat herbal 


\section{PENDAHULUAN}

Plasma nutfah tumbuh-tumbuhan mempunyai fungsi dan peranan penting bagi kehidupan manusia di muka bumi ini. Dari plasma nutfah inilah bisa diperoleh berbagai sumber daya genetik yang berfungsi sebagai obat, maupun dimanfaatkan pada bidang pemuliaan untuk merakit bibit-bibit tanaman dengan karakteristik yang unggul.

Tanaman binahong berasal dari Negeri Cina. Tumbuh menjalar pada tanaman lain dan panjangnya bisa mencapai lebih dari 5 $\mathrm{m}$, serta berumur panjang (Utami dan Desti 2013). Batangnya lunak saling membelit, berbentuk silindris, bagian dalam solid dengan permukaan halus, berwarna merah, kadang membentuk semacam umbi yang melekat di ketiak daun dengan tekstur kasar dan bentuk tak beraturan. Daun tunggal berwarna hijau dan bertangkai sangat pendek yang tersusun berselang-seling. Daun berbentuk hati dengan panjang 5-10 $\mathrm{cm}$, dan lebar 3-7 cm. Helaian daun tipis lemas dengan pangkal berlekuk, ujung runcing, permukaan licin dan tepi rata (Susetya 2012). Bunga binahong bertangkai panjang yang muncul di ketiak daun, dengan bunga majemuk berbentuk tandan berjumlah lima helai tidak berlekatan. Sedangkan mahkota bunga berwarna krem keputihputihan. Panjang helai mahkota $0,5-1 \mathrm{~cm}$ dan baunya harum. Akar berdaging lunak dan berbentuk rimpang (Palmer dan Senaratne 2012; Nuraini 2014). Tumbuhan ini mudah tumbuh di dataran rendah maupun dataran tinggi. Banyak ditanam di dalam pot sebagai tanaman hias dan obat. Umumnya dikembangkan secara generatif melalui biji, walaupun lebih sering diperbanyak melalui vegetatif dengan akar rimpangnya (Tanobat, 2016). Umbi terdapat di pangkal batangnya, dan bisa juga diperbanyak dengan umbi batang yang disebar di tanah.

Seluruh bagian tanaman binahong ini berkhasiat obat, mulai dari daun, batang hingga akarnya. Pemanfaatan daunnya bisa dimakan secara langsung sebagai lalapan atau direbus. Kini binahong telah dikemas dalam bentuk kapsul sehingga lebih mudah dikonsumsi. Dikenal sebagai tanaman obat ajaib karena binahong memiliki banyak khasiat, antara lain adalah melancarkan dan menormalkan peredaran dan tekanan darah, mempercepat penyembuhan luka, memper- cepat pemulihan kesehatan pasca operasi dan melahirkan (Miladiyah dan Prabowo 2012). Selanjutnya juga menyem-buhkan luka dalam, asam urat, radang usus, maag, ambeien, sariawan berat, diabetes, rematik, mencegah stroke, menambah dan mengembalikan vitalitas dan daya tahan tubuh, serta melancarkan buang air besar dan air kecil (Annisa 2007; Manoi 2009).

Daun binahong mengandung flavonoid, alkoloid polifenol dan saponin sebagai antimikroba. Aktivitas farmakologi dari flavonoid adalah sebagai anti-inflamasi, analgesik dan anti-oksidan (De Padua et al. 1999). Sebagai anti-kanker, ekstrak daunnya dapat menghancurkan sel-sel kanker servik (Yuliani et al. 2015). Ekstrak daunnya dibuat salep untuk menyembuhkan luka bakar pada kulit (Hidayati 2009). Ekstrak batang dan daun binahong juga berpotensi untuk menghambat pertumbuhan berbagai macam bakteri, temasuk Escherichia coli (Amertha et al. 2012; Darsana et al. 2012; Kartika et al. 2016) dan jamur (Kumalasari dan Sulistyani 2011).

Perbanyakan mikro secara kultur in vitro merupakan salah satu metoda perbanyakan tanaman secara vegetatif, yang salah satu tujuannya adalah untuk memperoleh bibit tanaman. Perbanyakan mikro tanaman merupakan contoh aspek yang menarik dari penerapan kultur jaringan. Penerapan metode ini memiliki keuntungan dapat digunakan untuk memproduksi bibit tanaman dalam jumlah besar dengan waktu singkat, terutama tanaman unggul yang baru dihasilkan.

Pengaruh dari suatu zat pengatur tumbuh bergantung pada spesies tumbuhan, tahap perkembangan tumbuhan, situs aksi zat pengatur tumbuh pada tumbuhan, dan konsentrasi zat pengatur tumbuh (George dan Sherrington 1984). Zat pengatur tumbuh tidak bekerja sendiri dalam mempengaruhi pertumbuhan dan perkembangan tumbuhan. Pada umumnya keseimbangan konsentrasi dari beberapa zat pengatur tumbuhlah yang akan mengontrol pertumbuhan dan perkembangan tumbuhan (Hendaryono dan Wijayani 2012). Hingga saat ini banyak peneliti yang memanfaatkan kultur in vitro sebagai cara alternatif dalam memproduksi metabolit sekunder dari jaringan dan kalus binahong dengan melakukan kultur kalus (Sitorus et al. 2011; Kuswandi dan Sugiyarto 2014; Mardini 2015; Rahayu dan Mardini 
Tabel 1. Susunan percobaan pengaruh tunggal zat pengatur tumbuh terhadap eksplan binahong

\begin{tabular}{llccc}
\hline \multirow{2}{*}{$\begin{array}{l}\text { Zat Pengatur } \\
\text { Tumbuh }\end{array}$} & \multicolumn{4}{c}{ Konsentrasi $(\mathrm{ppm})$} \\
\cline { 2 - 5 } BAP & 0,5 & 1,0 & 1,5 & 2,0 \\
\hline Kinetin & A1 & A2 & A3 & A4 \\
$2,4-D$ & B1 & B2 & B3 & B4 \\
\hline
\end{tabular}

2015; Widiyastuti 2015). Sedangkan kultur in vitro untuk perbanyakan mikro tanaman binahong belum ada yang melakukannya.

Tujuan dari penelitian ini adalah untuk melakukan kajian perbanyakan bibit pada tanaman binahong melalui kultur in vitro. Disamping itu juga untuk mengetahui pengaruh zat pengatur tumbuh auksin dan sitokinin, baik pada aplikasi tunggal maupun dalam kombinasi keduanya terhadap pertumbuhan dan perkembangan kultur eksplan tanaman binahong.

\section{BAHAN DAN METODE}

\section{Bahan tanaman}

Tanaman induk yang digunakan adalah tanaman binahong (Anredera cordifolia (Tenore) Steenis) yang vigor dan sehat dari kebun koleksi tanaman obat herbal Balai Bioteknologi BPPT di Kawasan Puspiptek Serpong. Tanaman induk dipilih yang telah berumur lebih dari 1 tahun dan bercabang banyak.

Pada percobaan zat pengatur tumbuh (ZPT) tunggal, eksplan yang digunakan adalah organ pucuk, daun muda dan batang muda. Pucuk diketahui mengandung hormon pertumbuhan auksin dan sitokinin yang sangat aktif, sedangkan daun mengandung bahan-bahan makanan bagi pertumbuhan tanaman. Batang muda terdiri dari sel-sel yang menyalurkan bahan-bahan makanan bagi pertumbuhan tanaman. Pada percobaan kombinasi, eksplan yang digunakan adalah organ pucuk dan batang muda. Eksplan yang dipilih disterilisasi dengan menggunakan tween 80 , alkohol $70 \%$, dan Na-hypochlorite $2 \%$.

\section{Pengaruh ZPT tunggal}

Penelitian in vitro dilakukan pada tanaman binahong untuk mengetahui
Tabel 2. Perhitungan besar kalus berdasarkan data kualitatif

\begin{tabular}{ccc}
\hline No. & Data Kualitatif & Diameter Kalus \\
\hline 1. & + & $0,1-0,5 \mathrm{~cm}$ \\
2. & ++ & $0,6-1,0 \mathrm{~cm}$ \\
3. & +++ & $1,1-2,0 \mathrm{~cm}$ \\
4. & ++++ & $2,1-3,0 \mathrm{~cm}$ \\
\hline
\end{tabular}

pengaruh tunggal zat pengatur tumbuh terhadap perkembangan dan pertumbuhan eksplan beserta organogenesisnya. Media dasar yang digunakan adalah media MS (Murashige dan Skoog 1962). Adapun zat pengatur tumbuh yang ditambahkan ke dalam media adalah BAP, kinetin dan 2,4-D. Masing-masing perlakuan diulang sebanyak 10 kali. Susunan percobaan yang dilakukan dapat dilihat pada Tabel 1.

Parameter yang diamati adalah pertumbuhan kalus, tinggi tunas yang terbentuk, jumlah daun per tunas dan jumlah ruas pada batang. Besar kalus diukur secara kualitatif berdasarkan skor + (1 plus) hingga ++++ (4 plus), dengan kriteria seperti tercantum pada Tabel 2.

\section{Pengaruh ZPT kombinasi}

Penelitian zat pengatur tumbuh secara kombinasi dilakukan untuk mengetahui pengaruhnya terhadap perkembangan dan pertumbuhan eksplan tanaman binahong beserta organogenesisnya. Kombinasi yang dilakukan merupakan perpaduan antara auksin dan sitokinin dengan konsentrasi yang berbeda. Adapun zat pengatur tumbuh yang digunakan adalah IAA yang dikombinasikan dengan BAP. Masingmasing perlakuan diulang sebanyak 10 kali. Susunan percobaan dicantumkan pada Tabel 3.

Parameter yang diamati adalah pertumbuhan tinggi tunas yang terbentuk, jumlah daun per tunas dan jumlah ruas pada batang per tunas. Ruang kultur untuk inkubasi eksplan dijaga agar temperatur tetap stabil pada suhu $25-27^{\circ} \mathrm{C}$ dengan intensitas cahaya 1000 - 2000 lux selama 12 jam. Eksplan yang telah terkontaminasi oleh mikroorganisme segera dipisahkan dan dikeluarkan dari ruang kultur. 
Tabel 3. Susunan percobaan pengaruh kombinasi zat pengatur tumbuh terhadap eksplan binahong

\begin{tabular}{lcccc}
\hline \multirow{2}{*}{ AUKSIN } & \multicolumn{4}{c}{ SITOKININ } \\
\cline { 2 - 5 } & BAP 0,5 & BAP 1,0 & BAP 1,5 & BAP 2,0 \\
\hline IAA 1,0 & A1S1 & A1S2 & A1S3 & A1S4 \\
\hline SITO- & \multicolumn{5}{c}{ AUKSIN } \\
KININ & IAA 0,5 & IAA 1,0 & IAA 1,5 & IAA 2,0 \\
\hline BAP 1,0 & A1S1 & A2S1 & A3S1 & A4S1 \\
\hline
\end{tabular}

\section{HASIL DAN PEMBAHASAN}

\section{Pengaruh ZPT tunggal}

Pada kajian ini tiga jenis zat pengatur tumbuh diuji pengaruhnya masing-masing secara tunggal terhadap berbagai eksplan binahong. Hasilnya tampak bahwa kalus terbentuk pada hampir semua perlakuan. Kalus telah mulai terbentuk sejak minggu pertama kultur.

Pada perlakuan BAP untuk eksplan pucuk, besar kalus terus meningkat dari konsentrasi rendah $(0,5 \mathrm{ppm})$ hingga konsentrasi 1,5 ppm. Namun pada konsentrasi BAP yang lebih tinggi, kalus tidak terbentuk sama sekali. Hasil yang mirip juga didapatkan oleh Sitorus dkk (2011). Mereka memperoleh berat kalus yang paling tinggi dari media yang mengandung BAP rendah $(0,4 \mathrm{ppm})$ dengan penambahan sukrosa tinggi (40 g/L). Tidak demikian halnya dengan eksplan daun muda dan batang muda. Pada kedua eksplan ini, semakin tinggi konsentrasi BAP maka kalus yang terbentuk akan semakin besar. Walaupun demikian, besar kalus yang diperoleh masih lebih kecil dibanding dengan kalus pada eksplan pucuk (Tabel 4).

Untuk perlakuan kinetin, kalus terbesar diperoleh pada konsentrasi yang paling rendah $(0,5 \mathrm{ppm})$ dari eksplan daun. Semakin tinggi konsentrasi kinetin, maka kalus yang dihasilkan akan semakin kecil. Sedangkan pada eksplan pucuk, pertumbuhan kalus cukup baik dan merata. Sebaliknya eksplan batang tampak kurang begitu merespon terhadap kinetin untuk pembentukan kalus, dimana kalus yang terbentuk berukuran kecil pada semua
Tabel 4. Besar kalus yang terbentuk pada eksplan daun dan batang muda binahong pada minggu ke- 6 setelah tanam

\begin{tabular}{clcccc}
\hline \multirow{2}{*}{$\begin{array}{c}\text { Zat } \\
\text { Pengatur } \\
\text { Tumbuh }\end{array}$} & Eksplan & \multicolumn{5}{c}{ Konsentrasi (ppm) } \\
\cline { 2 - 6 } & & 0,5 & 1,0 & 1,5 & 2,0 \\
\hline \multirow{3}{*}{ BAP } & Pucuk & ++ & +++ & ++++ & - \\
& Daun & ++ & +++ & +++ & +++ \\
& Batang & ++ & ++ & +++ & +++ \\
\hline \multirow{3}{*}{ Kinetin } & Pucuk & +++ & +++ & ++ & +++ \\
& Daun & ++++ & + & ++ & ++ \\
& Batang & + & ++ & ++ & ++ \\
\hline \multirow{3}{*}{$2,4-D$} & Pucuk & +++ & - & ++++ & +++ \\
& Daun & ++++ & +++ & +++ & +++ \\
& Batang & ++++ & ++++ & ++++ & ++++ \\
\hline
\end{tabular}

konsentrasi. Khairunisa (2009) juga memperoleh hasil yang serupa, yaitu kalus terbentuk pada sebagian besar perlakuan BAP dan kinetin.

Fenomena yang berbeda diperoleh dari zat pengatur tumbuh 2,4-D. Kalus yang terbentuk selalu lebih cepat (awal) dan berukuran besar, berapapun konsentrasi 2,4-D yang digunakan (Tabel 4). Sejalan dengan hasil yang diperoleh pada kajian ini, Kuswandi dan Sugiyarto (2014) mendapatkan induksi kalus yang cepat, yaitu 3 hari setelah kultur, pada perlakuan 1,0 ppm 2,4-D. Sedangkan kalus terlama diperoleh dari perlakuan 3,0 ppm 2,4-D, yaitu 11 hari. Sedangkan Rahayu dan Mardini (2015), serta Widiyastuti (2015) memperoleh kalus pada hari ke-7. Rentang waktu ini kurang lebih sama dengan hasil yang diperoleh dari penelitian ini.

Kajian pengaruh zat pengatur tumbuh tunggal pada eksplan pucuk binahong, dihasilkan pertumbuhan tunas, daun dan ruas yang ukuran dan jumlahnya beragam. Secara umum, nilai tertinggi diperoleh pada perlakuan BAP, baik tinggi tunas, jumlah daun maupun jumlah ruas. Sebaliknya nilai terkecil diperoleh pada perlakuan 2,4-D (Tabel 5).

Untuk parameter tinggi tunas pada eksplan pucuk dan batang, terlihat makin meningkat hingga konsentrasi BAP mencapai $1,5 \quad \mathrm{ppm}$. Selanjutnya pertumbuhan meninggi akan berkurang pada konsentrasi BAP yang lebih tinggi $(2,0 \mathrm{ppm})$. Fenomena yang sama juga tampak pada parameter jumlah daun. Jumlah daun bertambah dengan semakin tingginya konsentrasi BAP hingga 1,5 ppm, kemudian 
Tabel 5. Pengaruh zat pengatur tumbuh terhadap pertumbuhan eksplan pucuk dan batang muda binahong

\begin{tabular}{|c|c|c|c|c|c|c|}
\hline \multirow{2}{*}{$\begin{array}{l}\text { Zat Pengatur } \\
\text { Tumbuh }\end{array}$} & \multirow{2}{*}{ Eksplan } & \multirow{2}{*}{ Parameter } & \multicolumn{4}{|c|}{ Konsentrasi (ppm) } \\
\hline & & & 0,5 & 1,0 & 1,5 & 2,0 \\
\hline \multirow{6}{*}{ BAP } & \multirow{3}{*}{ Pucuk } & Tinggi Tunas (mm) & 25,5 & 20,0 & 64,5 & 18,0 \\
\hline & & Jumlah Daun & 5,5 & 6,0 & 8,5 & 3,0 \\
\hline & & Jumlah Ruas & 8,0 & 10,0 & 9,2 & 4,0 \\
\hline & \multirow{3}{*}{ Batang } & Tinggi Tunas (mm) & 12,5 & 15,0 & 24,5 & 15,0 \\
\hline & & Jumlah Daun & 2,0 & 2,8 & 6,0 & 2,8 \\
\hline & & Jumlah Ruas & 2,5 & 4,0 & 7,3 & 4,0 \\
\hline \multirow{6}{*}{ Kinetin } & \multirow{3}{*}{ Pucuk } & Tinggi Tunas (mm) & 14,0 & 32,0 & 17,0 & 24,5 \\
\hline & & Jumlah Daun & 1,5 & 6,0 & 2,0 & 4,0 \\
\hline & & Jumlah Ruas & 2,5 & 7,5 & 3,0 & 5,5 \\
\hline & \multirow{3}{*}{ Batang } & Tinggi Tunas (mm) & 19,5 & 26,8 & 17,7 & 19,3 \\
\hline & & Jumlah Daun & 3,3 & 4,8 & 2,3 & 3,8 \\
\hline & & Jumlah Ruas & 4,0 & 6,8 & 3,0 & 5,0 \\
\hline \multirow{6}{*}{$2,4-D$} & \multirow{3}{*}{ Pucuk } & Tinggi Tunas $(\mathrm{mm})$ & 46,0 & - & 23,5 & 53,0 \\
\hline & & Jumlah Daun & 6,0 & - & 3,0 & 7,5 \\
\hline & & Jumlah Ruas & 7,5 & - & 5,0 & 12,5 \\
\hline & \multirow{3}{*}{ Batang } & Tinggi Tunas (mm) & 25,0 & - & 17,0 & 11,5 \\
\hline & & Jumlah Daun & 1,5 & - & 0,5 & 2,3 \\
\hline & & Jumlah Ruas & 2,0 & - & 2,0 & 3,3 \\
\hline
\end{tabular}

jumlahnya kembali berkurang pada konsentrasi yang lebih tinggi. Namun untuk jumlah ruas, angka tertinggi didapat pada konsentrasi BAP 1,0 ppm pada eksplan pucuk dan 1,5 ppm pada eksplan batang. Di bawah dan di atas konsentrasi BAP tersebut menghasilkan jumlah ruas yang lebih kecil.

Zat pengatur tumbuh kinetin, dapat menghasilkan pertumbuhan yang baik, walaupun tidak setinggi BAP. Kinetin pada kadar 1,0 ppm menghasilkan pertambahan tinggi, jumlah daun dan jumlah ruas yang paling besar untuk kedua jenis eksplan, dibanding dengan kadar kinetin yang lain. Hasil ini sedikit berbeda dengan yang diperoleh Khairunisa (2009). Dari penelitiannya, konsentrasi $0,5 \mathrm{ppm}$ kinetin menghasilkan pertambahan tinggi dan jumlah daun yang terbaik.

2,4-D memberikan pengaruh negatif terhadap pertumbuhan dan perkembangan tunas dan daun pada tanaman binahong, kecuali parameter tinggi tunas pada eksplan pucuk. Tunas yang tumbuh pada eksplan batang, menghasilkan pertumbuhan yang terkecil, baik pada tinggi tunas maupun pada jumlah daun dan jumlah ruas.
Dari berbagai jenis eksplan yang diuji, tampak bahwa eksplan pucuk menghasilkan pertambahan tinggi tunas yang terbesar dibanding dengan eksplan-eksplan lainnya. Penelitian ini menunjukkan bahwa zat pengatur tumbuh dengan berbagai konsentrasi yang berbeda serta jenis eksplan tampak berpengaruh terhadap parameter yang diamati.

\section{Pengaruh ZPT kombinasi}

Kombinasi IAA dan BAP berpengaruh terhadap semua eksplan dan memberikan pola spesifik pada pertumbuhan dan perkembangan in vitro tanaman binahong. Pada eksplan pucuk dengan perlakuan 1,0 ppm IAA, semakin tinggi konsentrasi BAP maka pertumbuhan meninggi tunas akan semakin terhambat. Hal yang sama terlihat pada jumlah daun. Pertambahan konsentrasi BAP di dalam media akan menurunkan jumlah daun yang terbentuk. Namun sebaliknya untuk cabang, jumlahnya semakin meningkat dengan pertambahan konsentrasi BAP hingga 1,5 ppm, selanjutnya jumlah cabang akan menurun pada konsentrasi BAP yang lebih tinggi (2,0 ppm). Adapun untuk 
Tabel 6. Pertumbuhan eksplan binahong pada perlakuan kombinasi IAA dan BAP di minggu ke-6 setelah tanam

\begin{tabular}{|c|c|c|c|c|c|}
\hline \multirow{2}{*}{ Eksplan } & \multirow{2}{*}{ Parameter } & \multicolumn{4}{|c|}{ Konsentrasi IAA 1,0 ppm } \\
\hline & & BAP 0,5 & BAP 1,0 & BAP 1,5 & BAP 2,0 \\
\hline \multirow{4}{*}{ Pucuk } & Tinggi Tunas (mm) & 51,8 & 47,3 & 49,8 & 39,5 \\
\hline & Jumlah Daun & 11,3 & 9,3 & 7,8 & 9,5 \\
\hline & Jumlah Ruas & 10,5 & 9,8 & 10,0 & 9,5 \\
\hline & Jumlah Cabang & 1,0 & 1,5 & 2,5 & 1,8 \\
\hline \multirow{4}{*}{ Batang } & Tinggi Tunas (mm) & 43,8 & 48,0 & 47,5 & 36,0 \\
\hline & Jumlah Daun & 4,5 & 7,5 & 9,0 & 7,5 \\
\hline & Jumlah Ruas & 6,3 & 9,5 & 10,0 & 8,0 \\
\hline & Jumlah Cabang & 1,3 & 2,0 & 2,0 & 2,3 \\
\hline
\end{tabular}

Tabel 7. Pertumbuhan eksplan binahong untuk perlakuan kombinasi BAP dan IAA pada minggu ke-6 setelah tanam

\begin{tabular}{llcccc}
\hline \multirow{2}{*}{ Eksplan } & \multicolumn{3}{c}{ Karameter } & \multicolumn{3}{c}{ Konsentrasi BAP 1,0 ppm } \\
\cline { 3 - 6 } & Tinggi Tunas (mm) & IAA 0,5 & IAA 1,0 & IAA 1,5 & IAA 2,0 \\
\hline \multirow{3}{*}{ Pucuk } & Jumlah Daun & 42,8 & 57,8 & 70,3 & 59,0 \\
& Jumlah Ruas & 9,5 & 7,8 & 9,8 & 8,5 \\
& Jumlah Cabang & 9,5 & 9,3 & 12,5 & 9,0 \\
\hline \multirow{3}{*}{ Batang } & Tinggi Tunas (mm) & 1,5 & 3,0 & 1,8 & 3,0 \\
& Jumlah Daun & 42,3 & 45,8 & 40,3 & 6,3 \\
& Jumlah Ruas & 7,3 & 5,8 & 5,8 & 7,0 \\
\hline
\end{tabular}

jumlah ruas, menghasilkan pola yang berbeda. Parameter ini tidak begitu berpengaruh terhadap perbedaan konsentrasi BAP di dalam media kultur (Tabel 6).

Pada eksplan batang muda, parameter jumlah daun, jumlah ruas dan tinggi tunas berpengaruh terhadap perbedaan konsentrasi BAP dalam media. Jumlah kedua daun dan ruas meningkat hingga konsentrasi BAP mencapai 1,5 ppm. Kemudian jumlah tersebut menurun pada konsentrasi BAP yang lebih tinggi (2,0 ppm). Sedangkan parameter tinggi tunas, pertambahan konsentrasi BAP di dalam media akan menurunkan tinggi tunas. Namun untuk parameter jumlah cabang, tidak ada perbedaan terhadap berbagai konsentrasi BAP yang digunakan (Tabel 6).

Fenomena yang berbeda tampak pada perlakuan BAP yang dikombinasikan dengan berbagai level konsentrasi IAA pada kultur in vitro binahong. Pada eksplan pucuk dengan perlakuan 1,0 ppm BAP, pertambahan konsentrasi IAA hingga 1,5 ppm sangat berpengaruh terhadap pertumbuhan meninggi tunas dan jumlah ruas (Tabel 7). Setelah itu pertumbuhannya akan menurun pada konsentrasi IAA yang lebih tinggi (2,0 ppm). Sedangkan jumlah ruas tertinggi dicapai pada konsentrasi IAA 1,0 ppm. Selanjutnya jumlah tersebut akan menurun pada konsentrasi IAA lebih tinggi (1,5 dan 2,0 ppm). Untuk parameter jumlah daun, semua kadar konsentrasi IAA yang diuji tidak berpengaruh sama sekali, terlihat jumlah daun hampir sama banyak pada semua perlakuan.

Pada eksplan batang muda, pertumbuhan tertinggi umumnya diperoleh pada konsentrasi IAA rendah (0,5 ppm). Pertambahan konsentrasi IAA akan menurunkan jumlah daun, jumlah ruas dan jumlah cabang. Sedangkan untuk parameter tinggi tunas, berbagai konsentrasi IAA tidak menghasilkan perbedaan pertumbuhan (Tabel 7). Respon tumbuh yang dihasilkan dari penelitian ini menunjukkan bahwa perbedaan sumber eksplan dan kombinasi zat pengatur tumbuh sangat berpengaruh terhadap pertumbuhan dan perkembangan kultur in vitro binahong. Terlihat dari 
penelitian ini bahwa eksplan yang berbeda memberikan hasil yang berbeda. Demikian juga dengan zat pengatur tumbuh, jenis yang berbeda serta perbedaan kombinasinya menghasilkan pertumbuhan yang berbeda pula. Dari pelakuan kombinasi auksin dan sitokinin pada eksplan daun binahong, Kuswandi dan Sugiyarto (2014) memperoleh morfogenesis ke arah pembentukan tunas dan akar adventif dari kalus. Sebaliknya, Rahayu dan Mardini (2015) pada perlakuan 2,4-D menghasilkan pertumbuhan akar yang langsung muncul dari eksplan nodus dan daun.

Menurut George dan Sherrington (1984) pertumbuhan dan morfogenesis in vitro diatur melalui interaksi dan keseimbangan antara zat pengatur tumbuh yang diberikan ke dalam medium dan yang diproduksi secara alami oleh sel dan jaringan (endogenous). Sitokinin yang digunakan pada penelitian ini adalah BAP dan kinetin. Secara umum sitokinin menstimulasi pembelahan sel dan pembentukan tunas adventif dari kultur in vitro. Untuk kultur in vitro binahong, BAP pada kadar tertentu dapat merangsang pertumbuhan tinggi tunas, menambahan jumlah daun, dan ruas. Sedangkan kinetin, sebagai sitokinin pertama yang berhasi diisolasi di laboratorium Skoog (George dan Sherrington 1984), berperan pada penambahan tinggi tunas binahong pada kadar yang rendah.

Auksin yang diaplikasikan dalam penelitian ini adalah 2,4-D dan IAA. Dalam kultur in vitro, auksin pada konsentrasi yang rendah berpengaruh terhadap induksi kalus, merangsang pembentukan akar dan embriogenesis. Namun pada konsentrasi yang tinggi, auksin dapat menjadi racun yang mematikan tanaman (George dan Sherrington 1984). Untuk kultur in vitro binahong, penambahan 2,4-D ke dalam media telah menginduksi pembentukan kalus dengan ukuran yang besar. Sedangkan IAA, pada kadar rendah berperan untuk menambah jumlah cabang binahong. Hasil dari penelitian ini dapat digunakan pada studi lebih lanjut untuk meningkatkan laju dan efisiensi perbanyakan tunas pada tanaman binahong. Disamping itu juga untuk studi kultur kalus, baik menggunakan media padat maupun media cair, dalam memproduksi metabolit sekunder dari kalus binahong.

\section{KESIMPULAN}

Pada perlakuan 2,4-D kalus diproduksi dari semua eksplan binahong, yaitu pucuk, daun muda dan batang muda, dan ukuran kalus yang diperoleh juga besar (dengan diameter $>2 \mathrm{~cm}$ ). Namun sebaliknya zat pengatur tumbuh ini memberikan pengaruh negatif terhadap pertumbuhan dan perkembangan tunas dan daun. Untuk zat pengatur tumbuh yang lain, yaitu BAP dan kinetin, ukuran kalus yang diproduksi sangat tergantung pada konsentrasi zat pengatur tumbuh dan jenis eksplan. Ukuran kalus yang terbesar dihasilkan dari eksplan pucuk dengan perlakuan 1,5 ppm BAP, sedangkan pada perlakuan kinetin, diperoleh dari eksplan daun dengan konsentrasi zat pengatur tumbuh yang paling rendah (0,5 ppm).

Pada perlakuan ZPT tunggal, eksplan pucuk dengan perlakuan 1,5 ppm BAP menghasilkan pertambahan tinggi tunas $(64,5 \mathrm{~mm})$ dan jumlah daun $(8,5)$ yang paling besar. Sedangkan kinetin pada kadar 1,0 ppm menghasilkan pertambahan tinggi $(32,0$ dan $26,8 \mathrm{~mm})$, jumlah daun $(6,0$ dan 4,8$)$ dan jumlah ruas $(7,5$ dan 6,8$)$ yang paling tinggi untuk eksplan pucuk dan batang, dibanding dengan kadar kinetin yang lain.

Pada perlakuan kombinasi, hasil yang terbaik untuk parameter tinggi tunas dan jumlah daun diperoleh pada IAA dan BAP dengan konsentrasi rendah. Pada penelitian ini, kedua jenis eksplan yang diuji memberikan hasil yang sama untuk semua parameter yang diuji.

\section{DAFTAR PUSTAKA}

Amertha IBPM, Soeliongan S, Kountul C (2012) In vitro inhibition zone test of binahong (Anredera cordifolia) toward Staphylococcus aureus, Enterococcus faecalis, Escherichia coli, and Pseudomonas aeruginosa. Indones $\mathrm{J}$ Biomed Sci 6:30-34

Annisa N (2007) Uji aktivitas antibakteri ekstrak air daun binahong (Anredera scandens (L) Mor) terhadap bakteri Klebsiella pneumonia dan Bacillus substilis ATTC 6633 beserta skrining fitokimia dengan uji tabung. Skripsi, Fakultas Farmasi, UGM Yogyakarta

Darsana IGO, Besung INK, Mahatmi H (2012) Potensi daun binahong 
(Anredera cordifolia (Tenore) Steenis) dalam menghambat pertumbuhan bakteri Escherichia coli secara in vitro. Indones Medicus Veterinus 1:337-351

De Padua LS, Bunyaprahastra, Lemmens JR (1999) Plant Resources of Southeast Asia 12 (1) Medicinal and Poisonous Plant. Bogor. Porsea. pp. 286-287

George EF, Sherrington PD (1984) Plant Propagation by Tissue Culture Handbook and Directory of Commercial Laboratories. 709 p. Exegenetics Ltd. Basingstoke, UK

Hendaryono DPS, Wijayani A (2012) Teknik Kultur Jaringan - Pengenalan dan petunjuk perbanyakan tanaman secara vegetatif-modern. Cetakan ke-13. Kanisius Yogyakarta

Hidayati IW (2009) Uji aktivitas salep ekstrak daun binahong (Anredera cordifolia (Ten.) Steenis) sebagai penyembuh luka bakar pada kulit punggung kelinci. Skripsi, Fakultas Farmasi, Universitas Muhammadiyah Surakarta

Kartika GRA, Andayani S, Soelistyowati (2016) Potensi ekstrak daun binahong (Anredera cordifolia) sebagai penghambat bakteri Vibrio harveyi. J Mar Aquat Sci 2:49-53

Khairunisa R (2009) Penggunaan beberapa jenis sitokinin terhadap multiplikasi tunas dan pertumbuhan binahong (Anredera cordifolia (Ten) Steenis) secara in vitro. Skripsi. Institut Pertanian Bogor. Url: http:// repository.ipb.ac.id/handle/ 123456789/13677

Kumalasari E, Sulistyani N (2011) Aktivitas antifungi ekstrak etanol batang binahong (Anredera cordifolia (Tenore) Steen) terhadap Candida albicans serta skrining fitokimia. J IImiah Kefarmasian 1:51-62

Kuswandi PC, Sugiyarto L (2014) Morphogenetic effects of several plant growth regulator (PGR) on in vitro development of binahong (Anredera cordifolia L) leaf. Proceeding of International Conference on Research, Implementation and Education of Mathematics and Sciences pp B103108. Yogyakarta State University, Yogyakarta

Manoi F (2009) Binahong (Anredera cordifolia (Ten) Steenis) sebagai obat. J Warta Penelitian dan Pengembangan Tanaman Industri 15:3 Mardini U (2015) Pengaruh kombinasi 2,4-D dan BAP terhadap induksi kalus eksplan daun dan batang tanaman binahong (Anredera cordifolia (Ten.) Steenis) secara in vitro. Skripsi, Universitas Muhammadiyah Surakarta

Miladiyah I, Prabowo BR (2012) Ethanolic extract of Anredera cordifolia (Ten.) Steenis leaves improved wound healing in guinea pigs. Univ Med 31:4-11

Murashige T, Skoog F (1962) A revised medium for rapid growth and bioassay with tobacco tissue cultures. Physiol Plant 15:473-497

Nuraini DN (2014) Aneka daun berkhasiat untuk obat. Gava Media, Yogyakarta

Palmer B, Senaratne W (2012) Anredera cordifolia (Ten.) Steenis - Madeira vine. In: Julien $\mathrm{MH}, \mathrm{McF}$ adyen REC, Cullen JM (eds) Biological control of weeds in Australia. CSIRO Pub Collingwood, Australia, pp 60-64

Rahayu T, Mardini U (2015) Respon eksplan nodus dan daun tanaman binahong (Anredera cordifolia) pada media MS dengan variasi konsentrasi BAP. Prosiding Seminar Nasional XII Pendidikan Biologi FKIP UNS 2015, pp 657-661

Sitorus EN, Hastuti ED, Setiari N (2011) Induksi kalus binahong (Basella rubra L.) secara in vitro pada media Murashige dan Skoog dengan konsentrasi sukrosa yang berbeda. Bioma 13:1-7

Susetya D (2012) Khasiat dan manfaat daun ajaib binahong. Pustaka Baru Press, Yogyakarta

Tanobat (2016) Binahong - Ciri tanaman serta khasiat dan manfaatnya. http://www. tanobat.com/binahong-ciritanaman-serta-khasiat-dan-

manfaatnya.html. Diakses pada tanggal April 2016

Utami P, Desti EP (2013) The miracle of herbs - Daun, umbi, buah, dan batang tanaman ajaib penakluk aneka penyakit. PT AgroMedia Pustaka, Jakarta

Widiyastuti LO (2015) Induksi kalus pada eksplan batang tanaman binahong (Anredera cordifolia) secara in vitro 
dengan konsentrasi 2,4-D dan BAP yang berbeda. Skripsi, Universitas Muhammadiyah Surakarta

Yuliani SH, Anggraeni CD, Sekarjati W, Panjalu A, Istyastono EP, Setiawati A
(2015) Cytotoxic activity of Anredera cordifolia leaf extract on HeLa cervical cancer cells through p53-independent pathway. Asian J Pharm Clin Res 8:328-331 